\title{
SEMANTIC Constraints On Light Verb CONSTRUCTIONS IN MODERN IRISH
}

\author{
MARIA BLOCH-TROJNAR
}

\section{Introduction}

This paper is an attempt at formulating general semantic constraints on Light Verb Constructions (henceforth LVCs) in Modern Irish. Our discussion will focus on those LVCs or complex predicates which consist of a verb of general meaning and an action noun complement. ${ }^{1}$

(1)

a. Rinne sé aistriú air.

do-past he translate-VN on-it

'He translated it.'

(Ó Baoill \& Ó Tuathail 1992: 171)

b. Thug siad tógáil mhaith dá gclann. give-past they bring up-VN good to-their children

'They brought up their children well.'

(Ó Dónaill 1977: 1247)
D’aistrigh séé. translate-past he it

'He translated it.'

Thóg siad a gclann go maith. bring up-past they their children well 'They brought up their children well.'

1 The structures under consideration are part of a larger set. According to Wigger (2008: 246) constructions with "functional" verbs which "supply the required verbal nucleus" occur when verbs expressing the relevant notion do not exist or are stylistically marked as depicted in (i) and (ii) respectively:

(i) Lig sé fead. vs. *D'fhead sé. let-past he whistle

'He whistled.' (ii) Rinne sé gáirí. do-past he laugh-VN/laugther 'He laughed.'

He does not discuss VNs as possible complements in such structures and consequently all his examples contain morphologically simplex nouns as in (iii).

(iii)

$$
\begin{aligned}
& \text { cuir ceist /fáilte /tús /deireadh /spéis /dath } \\
& \text { put question /welcome /beginning /end / interest /colour } \\
& \text { 'to ask /welcome /begin /finish /interest /colour' }
\end{aligned}
$$

Abundant and compelling arguments for the nominal status of the verbal noun (henceforth VN) in LVCs can be found in Bloch-Trojnar (2006, 2009a). As will be observed in the examples cited throughout the paper, the $\mathrm{VN}$ is accompanied by strictly nominal modifiers such as the definite article, possessives, demonstratives, quantifiers, numerals, NPs in the genitive case and adjectives. Even in English the nominal status of the complement in LVCs is not taken for granted, e.g. Wierzbicka (1982), Kearns (2002), Stevenson et al. (2004) regard it as a verbal element whereas Jespersen (1954), Cattell (1984), Cetnarowska (1993) argue for its nominal status. 
The verb which serves as the base for the nominalisation appears as the main verb of the corresponding paraphrase, which points to the dominant semantic contribution of the VN. Interestingly, the arguments of the main verb reappear bearing the same thematic roles in an LVC. A natural question arises if any difference can be detected in the semantic interpretation of an LVC and that of a predicate with a corresponding simple verb.

According to Ó Siadhail (1989: 304) such constructions are used to achieve a partitive or singulative effect. This would be in line with a crosslinguistically widespread tendency for complex predicates among others to mark aspectual distinctions, which have to do with the internal constituency of an event. ${ }^{2}$ Therefore, in what follows we shall take a closer look at the aspectual characteristics of LVCs in Irish.

Subtle semantic modification including volitionality, benefaction, forcefulness is another characteristic trait of LVCs frequently pointed out in the pertinent literature (cf. Butt 2003, Butt and Geuder 2001). That is why in the second part of this paper we shall turn to the investigation of the interaction of the semantics of the light verb and the semantics of the verb which serves as the base for the complement with a view to establishing constraints which govern the combination of particular light verbs with nominalisations derived from various semantic classes of verbs, much in the same way as Wierzbicka (1982) and Cetnarowska (1993) have done for English. Wierzbicka (1982) demonstrated that by conducting a fine-grained semantic analysis it is possible to identify which words form a valid complement to a given light verb - in other words she provided a principled account of why have a drink is acceptable whereas *have an eat is not. Cetnarowska (1993: 54) convincingly argues that the choice of a specific light verb in the same language has a bearing on how we may view the action expressed by means of a complex predicate - "either as agentoriented, intentional or involuntary, pleasurable or necessitating great effort". This would imply that the semantics of LVCs in English is compositional and contrary to Jespersen (1954: 117-118) the "light" verb is not "an insignificant verb" to which merely "the marks of person and tense are attached".

The inventory of light verbs employed in Irish LVCs is fairly impressive. Ó Siadhail (1989: 304-308) enumerates the following: déan 'do', ${ }^{3}$ tabhair 'give', lig 'let' and caith 'spend, throw'. A list by Wigger

2 Wierzbicka (1982) argues for the telicising character of LVCs in English. An element of boundedness or telicity in LVCs can also be observed in Urdu, Hindi and other South Asian languages (see Butt 2003 and the references therein).

3 The light verb déan 'do' should be kept distinct from an auxiliary ( $c f$. Ó Dochartaigh 1992: 32, 57) which appears as a periphrastic variant of impersonal or future forms of 
(2008) additionally comprises faigh 'get', cuir 'put', téigh 'go' and tag 'come'. These two lists could be supplemented with bain 'take, extract'. For the discussion at hand we have selected four light verbs: déan 'do', tabhair 'give', faigh 'get' and bain 'take, extract'.

Our main source of data are standard dictionaries such as Ó Dónaill (1977), de Bhaldraithe (1959) and Dinneen (1927). The corpus devised by Ó Duibhín (2006) was the main source of examples from literary texts. ${ }^{4}$

\section{The telic character of LVCs in Irish}

In what follows it will be argued that LVCs in Irish are a means of telicising activities - they specify a spatiotemporal limit on the entities in the extension of the predicate. ${ }^{5}$

Brinton (1998: 38-9) rightly points out that "the entire VP enters into the expression of aktionsart”, e.g. run is an activity verb (atelic), but the predicate run (home, to the corner) contains an endpoint/goal and is thus an accomplishment (telic). Therefore, in the aspectual interpretation of complex predicates apart from the temporal characteristics of states of affairs denoted by particular VN complements (their aktionsart) ${ }^{6}$ we need to include the range of quantifying, nominal and spatio-temporal expressions accompanying the $\mathrm{VN}$.

In a traditional classification of situation types (Vendler 1967) the crudest distinction is made between continuities and events. The former encompass states and activities whereas the latter subsume accomplishments, achievements and semelfactives. The table below (modelled on the figure from Brinton 1998: 38) lists the five abovementioned situation types together with their characteristics and examples from Irish.

polysyllabic verbs, i.e. Dhéanfaidh mé sin a cheannacht duit = ceannóidh mé sin duit 'I will buy that for you'.

4 Bearing in mind the limited character of our scope and data, this analysis is to be regarded as a preliminary sketch designed to instigate further more extensive research in this area. Ó Duibhín (2006) is a textbase which consists of several collections of texts and it enables the user to search for words and observe their usage in context. Among others it contains three collections of texts in Connacht Irish (Ó Direáin 1961, Ó Ruadháin 1967, Mag Uidhir 1944) and two in Munster Irish (Ó Dálaigh 1933, Ua Maoileoin 1960). I would like to thank Mark Ó Fionnáin of John Paul II Catholic University of Lublin for his invaluable help in translating the Irish examples.

5 Aspectuality of LVCs in Irish is subjected to a detailed analysis in Bloch-Trojnar (2009b) and in this section we shall present a summary of those issues that are relevant to the discussion at hand.

6 For a detailed explanation of the Aspect vs. Aktionsart distinction the reader is referred to Brinton (1988). 
(2)

\begin{tabular}{|l|l|l|}
\hline Situation type & Characteristics & Irish \\
\hline states $^{7}$ & static, durative, nontelic & amharc 'see', creid 'believe' \\
\hline activities & dynamic, durative, nontelic & $\begin{array}{l}\text { ól 'drink', imir 'play', codail } \\
\text { 'sleep' }\end{array}$ \\
\hline accomplishments & dynamic, durative, telic & $\begin{array}{l}\text { teach a thógáil 'build a } \\
\text { house', rás a rith 'run a race' }\end{array}$ \\
\hline achievements & dynamic, punctual, telic & $\begin{array}{l}\text { dúnmharaigh 'murder', } \\
\text { dúisigh 'wake' }\end{array}$ \\
\hline semelfactives & $\begin{array}{l}\text { dynamic, punctual, telic } \\
\text { iterative meaning in the } \\
\text { progressive }\end{array}$ & léim 'jump', spléach 'glance' \\
\hline
\end{tabular}

Telicity of LVCs in Irish is compositional in that it results from the interaction of lexical information and syntax. Let us now observe how the syntactic contribution varies depending on the situation type of the verb which serves as the base for the VN.

Verbal predicates which contain an inherent endpoint or individuating boundary due to their lexico-semantic specification (i.e. are telic) do not require additional individuation at the syntactic level. Hence, LVCs with verbal nouns derived from accomplishments and achievements are equivalent to inflected verbs and need not be further individuated contextually, as in (1a) and (1b) above or in (3a) and (3b) below:

(3)

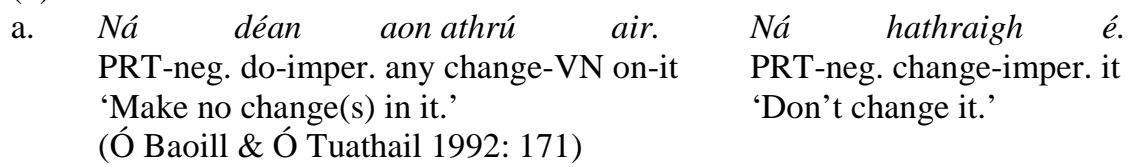
b. Thug sé diúltú.
give-past- $3^{\text {rd }}$ sg.ind. he refuse-VN
'He gave a refusal/He refused.'
Dhiúltaigh sé. refuse-past- $3^{\text {rd }}$ sg.ind. he 'He refused.'

(Ó Dónaill 1977: 419)

Semelfactive verbs such as léim 'jump' impose a single event reading (cf. Cetnarowska 1993: 44-46, Brinton 1998: 5, Willim 2006: 119). Being inherently individuated they can be counted and multiplied.

7 The inventory of stative verbs in Irish was reduced in the course of diachronic development. Wagner (1959: $127 \mathrm{ff}$ ) demonstrates that in early Irish there were more stative as well as dynamic verbs: ad-ágathar 'fears', do-futhraccair 'wishes', admuinethar 'remembers' etc. However, in the modern language such concepts are expressed by means of constructions involving nouns:

ad-ágathar > tá eagla air 'is fear on-him; he is afraid'

do-futhraccair > is áil leis; is mian leis 'is wish with-him; he wishes'

ad-muinethar > tá cuimhne aige ar 'is memory at-him about; he remembers' 
(4)

a. Ná tabhair léim na díge sin.

neg. give-imper. jump-VN the ditch-gen. that

'Don’t jump that ditch.' (Ó Dónaill 1977: 1187)

b. Thug sí léim eile, agus thúirling sí thar náis.

give-past she jump-VN other and descend-past she back

'She gave another jump and descended back.' (Ó Dálaigh 1933: 139)

c. Bhí sí ó léim go léim marsingodtígurthug síaon léim amháin was she from jump-VN to jump-VN like this until PRT give-past she one jump only ardeire thiarthall agus gur thúirling sí agebun na spéireach in the end west beyond and PRT descend-past she at bottom the sky-gen. amuigh insa bhfairrge doimhin.

out into sea deep

'She was from jump to jump this way (was jumping this way) until she gave one jump in the end and she descended at the bottom of the sky out in the deep sea.' (Ó Dálaigh 1933: 139)

However, syntax has an important contribution to make in LVCs involving VNs derived from continuities. The telicising nature of LVCs manifests itself in their occurrence with cardinal numbers, enumerative determiners (e.g. amháin '(only) one', eile 'another', chéad 'first', iomaí 'many', cúpla 'a few') ${ }^{8}$ and adverbials (cúpla uair 'a few times', arís 'again' ${ }^{9}$ ), which provide the necessary counting criterion.

States are homogenous as any part of the situation they denote is like the entire situation and in LVCs we can only count the occasions of a given state. Note the modifiers in the examples below:

(5)

a. D'imíomair orainn siar abhaile, agus go fuaireas mo chéad amharc ar go-past-we on-us westwards home, and PRT get-past-I my first see-VN at Thomás Criothain.

Tomas Criothain

'We proceeded homewards, and I first saw Tomas Criothain.' (Ua Maoileoin 1960: 152)

b. Bean a bhí thoir in aice le hOileán Ciarraí a fuair amharc súl woman that was east near island Kerry that get-past see-VN eye-pl. ar Phiaras cúpla uair agus do thit sí í ngrá leis...

on Piaras couple time and PRT fall-past she in love with-him

8 Brinton (1998: 50) explains that "the result of multiplying situations (no matter what their type) a specific number of times is a situation of the accomplishment type. Thus, to ascend a mountain (an accomplishment) two times or to run (an activity) five times both take a certain amount of time; they have necessary endpoints, namely when the two or five repetitions are completed".

9 If activities are perceived as occurring in bounded episodes they are replicable (Langacker 1987: 80). 
'There was a woman over east in Castleisland [in Co Kerry] who saw Piaras a couple of times and fell in love with him' (Ua Maoileoin 1960: 104)

c. Cá bhfios nachésin an t-aon amharc amháin a gheofá orthu ... how knowledge is-not it that the one see-VN only that get-cond.-you on-them 'Who knows that that isn't the only look you'd get of them/ maybe this is the last time you see them’ (Ó Direáin 1961: 130)

Consider the following examples of LVCs involving activity verbs:

(6)

a. Thug mé féachaint amháin orthu.

give-past I look-VN only on-them

'I took one glance at them.' (Ó Dónaill 1977: 522)

b. Tabhair téamh beag eile don bhainne.

give-imper.-you warm-VN small another to-the milk

'Warm the milk a little more.' (Ó Dónaill 1977: 1217)

c. Gearrann siad 'na bpíosaí iad ardtúis, agus cuireann siad cut-pres.ind. they in-the pieces them on beginning and put-pres.ind. they na píosaí ar bogadh síos i n-uisce fuar, tamall maith den lá, agus the pieces on soften-VN down in water cold time good of-the day and annsan cuireann siadag beirbhiú iad go dtí go mbaineann siad then put-pres.ind they PRT boil-VN them until PRT get-pres.ind. they

dhá fhliuchadh asta.

two wet-VN from-them

'First they cut them into pieces and they put the pieces into cold water to soak for a good part of the day, and then they set them boiling.'

(Ó Dálaigh 1933: 85)

d. Is iomaí cardáil a rinneadh ar an scéal sin. is many wool-carding-VN PRT was-done on the story that 'That story has often been sifted, debated.' (Ó Dónaill 1977: 191)

e. Déan do mhachnamh arís air. do-imper.-you your think-VN again on-it 'Think it over.' (de Bhaldraithe 1959: 755 )

f. Déan cúpla scrabhadh leis an scian air. do-imper. a few scratch-VN with the knife on-it 'Score it a few times with a knife.' (Ó Dónaill 1977: 1063)

Activities give rise to two dominant readings in LVCs. Firstly, continuous activities, such as sleeping or walking denote an activity lasting for some unspecified but limited period of time, i.e. a bounded portion. Note the modifier geábh in (7a), which means '(short) run, (quick) trip, (hurried) spell of activity'. Atelic verbs can denote conclusive situations if they are accompanied by time adverbials containing an endpoint in their semantic 
structure or adverbials indicating destination - John was walking (activity) vs. John walked to the shore (accomplishment).

(7)

a. geábh siúil a dhéanamh 'to do a spell of walking’ (Ó Dónaill 1977: 616) geábh spaisteoireachta a dhéanamh sa ghairdín 'to take turn in the garden' (de Bhaldraithe 1959: 787 )

b. Má chíonn siad go mbíonn aon dlús feamnaighe ionnta, ní mór an if see they that is one compactness seaweed in-them, is-not big the codladh a dheineann siad an oidhche sin. sleep-VN that make they the night that 'If they see that there is any seaweed in them, they don't get much sleep that night.’ (Ó Dálaigh 1933: 31)

c. Pé siúl a dhein an t-iascaire go dtí an dtig ... whatever walk-VN PRT did the fisherman to the house 'Whatever brought the fisherman walking to the house / The fisherman happened to walk to the house...' (Ó Siadhail 1989: 304)

Iterative activities which can be conceptualised as a series of discrete parts such as shaking when nominalised in LVCs will refer to a single subevent (a semelfactive).

(8)

a. Bhain sé croitheadh as an buidéal. extract-past he shake-VN from the bottle

'He shook the bottle.' (de Bhaldraithe 1959: 651)

b. Bhí gach aon chroitheadh millteanachá bhaint as an traein. was each/every shake-VN terrible PRT extract-VN from the train 'The train jolted terribly.' (de Bhaldraithe 1959: 384)

In sum: LVCs contain a telic component and impose a spatiotemporal limit on the predicate. The situation types in LVCs are accomplishments, achievements or semelfactives.

\section{General tendencies in complement selection and the semantic contribution of the light verb}

\subsection{Theoretical issues and preliminary remarks}

The semantic interpretation of LVCs arises as a result of interaction between the argument structures of the light verb and its complement. The complement provides semantic contents in the form of theta-roles that need to be licensed in syntactic positions, which is the responsibility of the light verb. Bearing in mind the cross-linguistic prevalence and diversity of LVCs, linguists are far from unanimous as to the exact nature of this 
interaction. There are proposals, in which the verb is regarded merely as locus for agreement and tense morphology and has no influence on the number and type of arguments ${ }^{10}$ side by side analyses involving argument structure composition ${ }^{11}$ in which light verbs have partially specified argument structures which are shared, fused, superimposed on or merged with the argument structure of the complement. As this paper is empirically oriented, a full exposition and evaluation of the theoretical intricacies of their interpretation would go far beyond its scope.

The results of a preliminary investigation of the Irish data suggest that light verbs in this language are not merely function words without thematic information. We can observe regularities in complement selection in that the theta-grid of the complement contains roles which are compatible with the roles of the light verb. This will be illustrated in section 3.2 below.

In addition to this, in section 3.3 it will be suggested that the choice of a specific light verb apart from contributing telicity and participant information may add a subtle semantic modification.

\subsection{Tendencies in complement selection}

We will now turn to the presentation of major semantic classes of verbs which are most likely to serve as bases for VNs assuming the role of complements of LVCs in Irish. The corpus used in this part is Ó Dónaill (1977). It appears that in terms of thematic grids the light verb and the complement obey the general condition of congruence (Jayaseelan 1988: 93), i.e. the thematic grid of the light verb and that of its complement are congruent but not necessarily identical. ${ }^{12}$

10 This position was articulated by Grimshaw \& Mester (1988) in their Argument Transfer analysis of suru-constructions in Japanese, where it is argued that the argument list of the lexical entry of the light verb is empty and "suru resembles in many ways the do of English Do Support, which carries inflection but assigns no $\theta$-roles and imposes no selectional restrictions" (Grimshaw \& Mester 1988: 211). Similar reasoning as applied to English can be observed in Cattell (1984). There are analyses in which light verbs are regarded as subtype of auxiliary (cf. Butt 2003).

11 These proposals introduce the mechanisms of Predicate Composition, Argument Merger or Argument Fusion (for a detailed discussion of these most recent proposals see Butt 2003 and the references therein). Jackendoff (1974) invokes the Complex Predicate Rule, which produces the subcategorisation frame for the complex predicate by removing the object position from the light verb and semantic interpretation is the result of "superimposing parallel semantic functions" of the main verb and the nominal (Jackendoff 1974: 490). This proposal echoes in Piñango, Mack and Jackendoff (2006) who look at English LVCs from a processing perspective and assume argument sharing - "the light-verb stipulates the syntactic role object without a corresponding thematic role, and the nominal stipulates thematic roles without corresponding syntactic roles".

12 Jayaseelan (1988: 93) argues that congruence is to be understood as a weaker relation than that of identity. "Agent and Patient are more distant from each other than, say, Patient and Theme, and a syntactic process may treat the latter pair (in contrast to the 
In view of the general lack of agreement between linguists as to the number and character of theta-roles, in order to avoid an over-analytical approach, we are going to use the terms such as Agent, Theme, Source, Recipient etc. as convenient mnemonic terms to formulate generalisations concerning the data, but they are not meant to carry any theoretical weight. ${ }^{13}$ Some category labels employed by Levin (1993) with reference to English will be utilised here. ${ }^{14}$

\subsubsection{LVC with déan 'do, make'}

Due to its general semantics, by far the most prevalent verb used in LVCs in Irish is déan, which implies both an abstract verb of action 'do, perform' and a verb of bringing into existence 'make, create'. Its thematic grid can be envisaged as containing an Agent and Theme/Patient or Affected Object/Result.

The de-verbal nominalisation in the $V N$ a dhéanamh 'make/do VN' frame is derived predominantly from activity verbs, which involve physical action and entail volition, i.e. verbs which typically take a human subject as Agent, actively controlling the action expressed by the verb. There are virtually no verbs denoting activities or states experienced by humans, i.e. verbs whose subject assumes the semantic role of Experiencer or Recipient, i.e. Psych-verbs which designate a change in psychological or emotional state. Verbs expressing cognitive activities must be relatively dynamic. So even if stative verbs such as beathnú, machnamh, smaoineamh, staidéar 'consider, contemplate' are attested they are used as activity verbs, e.g. rinne mé staidéar maith air 'I gave it much thought' (Ó Dónaill 1977: 1159). Perception verbs attested in that construction (faire, feighil 'keep watch', scrúdú 'examine') should also be understood as activity verbs, which denote longer actions involving some commitment on the part of the doer.

In the light of corpus studies in English (unfortunately no such studies are available for Irish) which show that activity verbs belong to most

former pair) as nondistinct for its purposes. Location and Experiencer can be superimposed whereas Agent and Experiencer cannot."

The role of Agent is assigned to a personal, volitional and causative participant. The Theme role characterises entities which undergo a change of state or location. Patients designate entities affected in the course of action instigated by Agents. Verbs of motion assign the roles of Source and Goal. If the end-point of movement is a human participant it bears the role of Recipient. There is also involuntary Causer and the roles of Experiencer and Experienced.

14 We are well aware of the fact that the actual category members may be different for both languages. It is important to note the problems inherent in any classification. Verbs can have meanings from different semantic domains, and in some cases the verb is most common with a non-core meaning. In such cases the verb is listed in the category reflecting its most typical use (cf. Biber et al. 1999: 361). 
frequently used (Biber et al. 1999: 365), their prominent position does not come as a surprise. The most conspicuous subclass of these employed in the LVC in question are verbs relating to communication and transfer of ideas. $^{15}$

\section{VERBS OF COMMUNICATION AND TRANSFER OF IDEAS: Agent,} Theme, Goal/Recipient

beannú 'bless'; moladh 'praise'; casoid, eagnach, gearán 'complain'; comhra 'conversation'; togairt 'allude'; trácht 'mention'; dearbhú, fogairt 'declare, confirm'; fiafraí 'ask'; maoímh 'boast'; iomardú 'reproach'; tairiscint 'offer'; tairngreacht, tuar 'prophesy'; conspóid 'argue'; seoladh 'direct, guide’; impí 'entreat'; cúiseamh 'accuse'; díotáil, iomardú 'indict'; éileamh 'claim, demand'; socrú 'agree'; margáil 'bargain'; dealú 'distinguish'; bagairt 'utter a threat'

Other prominent sense groups are activity verbs which denote an action of some duration which requires some effort on the part of the agent. Their thematic grid contains Agent and Theme/Affected Object ${ }^{16}$ and they comprise the following:

VERBS OF CREATION AND TRANSFORMATION: Agent, Theme/Affected Object

obair 'work'; streachailt 'struggle'; maistreach 'churn'; rómhair 'dig'; cur 'sow'; deargadh 'turn up (soil)'; súisteáil 'thresh'; foghlaim 'learn'; taighde 'research'; staidéar 'study'; paisteáil 'patch'; scuabadh 'sweep'; iascach 'fish'; soláthar 'gather'

VERBS OF DAMAGE AND CONTACT BY IMPACT: Agent, Patient/Affected Object

díobhail, loit 'injure'; speireadh 'hamstring'; scláradh, scoradh 'lacerate'; réabadh 'tear up'; goradh 'beat'; sceanach 'knife'; gránú 'scratch'; ionsaí 'attack'; deighilt, scaradh 'divide, separate'

15 As can be gleaned from the list above, these verbs predominantly denote actions with two or three participants: the Agent participant and the Theme which relates to the contents of the locution in question and/or the Goal (the recipient of information). The Goal/Recipient and the Theme in the LCS of the nominal complement may be licensed by the matrix verb déan with the aid of PPs with specialised prepositions, le 'with' + Recipient, faoi 'about' + Theme, ar 'on/in relation to/against'+ Patient/ Affected Object e.g. socrú a dhéanamh le duine faoi rud 'reach an agreement with s.o. about sth' (Ó Dónaill 1977: 1129), argóint a dhéanamh le duine faoi rud 'argue with s.o. about sth' (de Bhaldraithe 1959: 32); rinne sé casaoid faoin teas 'he complained about the heat' (de Bhaldraithe 1959: 136); rinne sé casaoid orm 'he lodged a complaint against me' (de Bhaldraithe 1959: 136); rinne sé casaoid 'he made a complaint' (Ó Dónaill 1977: 195).

16 If present in LVCs, the Affected Object/Patient/Theme features in a PP headed by ar, as in e.g. rinne tú soláthar maith ar na pingini 'you put a good few pence together' (Ó Dónaill 1977: 1133). 
There is a numerous group of verbs relating to change of state or possession.

CHANGE OF STATE: Agent,Theme/Affected Object

neartú 'strengthen'; réiteach 'level'; laghdú 'weaken’; ísliú 'lower', éirí 'rise'; dreo, finiú 'decay ${ }^{17}$

CHANGE OF POSSESSION: Agent, Theme/Affected Object

ceannach 'buy'; díol 'sell'; seiftiú 'provide'; íoc 'pay'; goid 'steal'; diomailt 'waste, squander'

There is also a special group of verbs relating to ingestion of food and drink.

VERBS OF INGESTING: Agent,Theme/Affected Object

stánáil, forlíonadh 'fill up, gorge oneself'; slogadh 'gulp down'; ól 'drink'

Intransitive verbs which serve as bases for VNs are mostly motion verbs with emphasis on manner of motion.

VERBS OF MOTION: Agent

siúl 'walk, travel'; máirseáil 'march'; snamh 'swim'; seilg 'chase, hunt'; géarú 'hurry'; seadú 'remain, linger'; damhsa, rince 'dance'

To recapitulate and round up, the hallmark of the $V N$ a dhéanamh frame is that it is Agent-oriented as stress is placed on the conscious action of an Agent who may create some effect on the Recipient/Patient/Affected Object either in the form of acquired information, sustained damage or changed appearance or state. Agent and the action itself are in focus.

\subsubsection{LVCs with tabhair}

As far as the verb tabhair do 'give to' < subject=Agent ${ }_{1}$, object=Theme ${ }_{2}$ ' do $\mathrm{NP}=\mathrm{Goal}_{3}>$ and its patterning are concerned, it should be observed that similar sense groups can be distinguished as in the construction with déan 'do, make'. Also the Agent is a human being that performs intentional acts. However, the indirect object expressed by means of a PP denotes Patients, Recipients or Beneficiaries, hence the change of perspective - the Goal also comes to the foreground.

Therefore, it shouldn't come as a surprise that in the construction $V N a$ thabhairt do dhuine/rud 'give $\mathrm{VN}$ to sb/sth' the pride of place belongs to verbs of social interaction, verbs of contact by impact and verbs of exerting

17 These two are the only verbs which do not take a volitional agent. Also weather verbs violate this requirement e.g. múraíl - ag múraíl 'showering': déanfaidh sé múraíl 'it will rain’ (Ó Dónaill 1977: 890); rinne sé sioc aréir 'there was frost last night' (Ó Dónaill 1977: 1096). 
force. These verbs denote "activities that inherently involve more than one participant” (Levin 1993: 200). Consequently, a large portion of these relate to fighting and verbal interactions. Ó Siadhail (1989: 307) notes this use of tabhair with "verbs of infliction".

VERBS OF SOCIAL INTERACTION: (mostly fight/quarrel and help)

Agent, Theme, Patient/Recipient

cuimilt, gearradh, sciúradh, scrabhadh (teanga) 'scold'; feannadh, roiseadh 'criticise, flay'; ullmhú 'chastise'; cargáil 'wrestle'; cíoradh 'fight'; raiceáil, iospairt 'maltreat'; indeargadh 'put to shame'; diultú, éaradh, eiteach 'refuse'; ligean 'allow'; cuidiú, cúnamh, fóirithint, fortacht, tarrtháil 'help'

VERBS OF CONTACT BY IMPACT: Agent, Patient/Affected Object flípeáil 'beat severely'; giolcadh 'cane'; greadadh, greasáil, leasú, liúradh, rúscadh, stánáil 'beat, trounce'; súisteáil 'flail’; cíorláil ‘tousle’; gleadhradh 'beat noisily, pummel'

VERBS OF EXERTING FORCE: Agent, Patient/Affected Object

brú 'shove'; fáiscadh 'squeeze'; priocadh 'dig'; sá 'thrust'; tarraingt 'pull'; cuimilt 'rub'; radadh 'throw'; bogadh 'move'; sciúradh, scrabhadh 'scour, scrub'; sciobadh 'snatch'; deochadh 'immerse'

Other relatively numerous sense groups include:

VERBS OF COMMUNICATION: Agent, Theme, Recipient/Goal

deimhniú 'certify'; faisnéis 'inform'; saoradh 'assure’; léiriú 'clarify’; móiniú 'explain'

CHANGE OF STATE/POSSESSION: Agent/Affected Object

fionnuarú, fuarú 'cool'; goradh 'warm'; léiriú 'clarify'; móiniú 'smooth'; cúiteamh 'compensate'; díol 'pay'

As in the case of déan, tabhair is not likely to occur with Psych-verbs (crá 'distress' being the only attested item in our corpus). Still, it is attested with judgement verbs which relate to opinion or judgement somebody may have in reaction to something. It is to be noted that this class was not attested in the VN a dhéanamh frame.

JUDGEMENT VERBS: meas, barúil 'think'; créidiúint 'believe'; maitheamh 'forgive'

In addition to this, there are more perception verbs with a human agent controlling the visual or auditory perception.

PERCEPTION VERBS: (mostly sight verbs) Recipient, Theme amharc, féachaint, silleadh, spleáchadh, leagan súl 'look'; éisteacht 'listen' 
If we compare the semantic domains of déan and tabhair, we will observe some overlapping and complementarity. Both verbs occur with verbal nouns from the same sense groups but to a varying extent. The former is most likely to occur with verbs of communication, motion, creation and transformation, whereas the latter has a preference for verbs of social interaction, verbs of contact by impact and verbs of exerting force - it occurs with only two verbs of motion fiach 'chase', léim 'jump' and one verb of ingestion ithe 'eat'.

\subsubsection{LVCs with faigh}

The verb faigh 'get' < subject=Goal ${ }_{1}$, object=Theme ${ }_{2}>$ is used in the $V N a$ fháil 'get VN' frame to describe the situation in such a way as to highlight the Experiencer or the Patient, i.e. a person or thing at whom/which the action is directed. This verb has the opposite semantics to tabhair, therefore we expect to find similar sense groups of VN with which they combine in LVCs. Our prediction is borne out in that the bases for the VN will predominantly be verbs with a volitional Agent effecting some change in the Patient. As with tabhair the most numerous groups are verbs of social interaction and verbs of contact by impact.

VERBS OF SOCIAL INTERACTION: Agent, Recipient/Affected Object/Patient deisiú, goradh 'scold'; cargáil 'wrestle'; iospairt 'maltreat'; fortacht 'help'

VERBS OF CONTACT BY IMPACT: Agent, Patient/Affected Object leadradh 'beat'; bascadh 'bash'; bualadh 'hit, beat'; ramhrú 'batter'; goin 'wound'

PERCEPTION VERBS: Recipient, Theme amharc, spleáchadh 'look'; blaiseadh 'taste'; éisteacht 'listen'

CHANGE OF STATE: Agent, Theme/Affected Object

aothú 'pass crisis'; goradh 'warm'; ardú 'move up'

VERBS OF COMMUNICATION (transfer of message): Agent, Theme, Patient/Recipient

múineadh, teagasc 'teach, train'; saoradh 'assure'

We find complementary pairs such as:

(9)

a. fortacht a thabhairt do dhuine 'come to the aid of s.o.' (Ó Dónaill 1977: 575) vs.

fortacht a fháil 'get relief'(Ó Dónaill 1977: 575)

b. Ní bhfuair sé éisteacht. 'He was refused a hearing.' (Ó Dónaill 1977: 494) vs. Ní thugann sé éisteacht ar bith dom. 'He pays no attention to what I say'

(Ó Dónaill 1977: 494) 
c. an spreagadh nach bhfuair sé 'the encouragement he didn’t get' (Ó Dónaill 1977: 1148) vs.

Is iondúil gur i mBéarla a léann sé na hábhair a thugann aon spreagadh dó. 'Usually it is in English that he reads any subjects that inspire him.'

(Ó Direáin 1961: 87)

Focus on particular participants is achieved by the choice of one light verb and not the other.

In contradistinction to tabhair, there seem to be verbs which take a human subject as Experiencer, undergoing but not controlling the action expressed by the verb or verbs.

PSYCH-VERBS: Agent/Cause, Experiencer/Goal

crá 'distress', céasadh 'torment'; coscairt 'distress'; leathadh 'distress, be perished';

It requires VNs with Recipient/Affected Object/Experiencer in their thematic grid. That's why no intransitive verbs are attested as possible bases for VNs in this frame.

\subsubsection{LVCs with bain}

Let us now turn to the discussion of the verb bain 'take out,

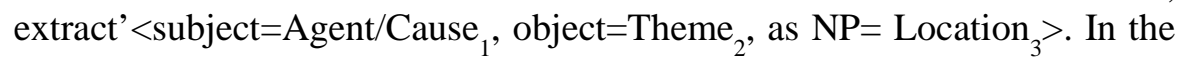
thematic grid of rud bhaint as dhuine/rud 'extract sth from s.o./sth' construction we have two participants: a voluntary Agent or involuntary Cause and an Experiencer/Patient/Affected Object. The following major classes motivating VNs have been identified:

CHANGE OF STATE: Agent, Affected Object/Patient

fiuch 'boil'; filleadh, feacadh, fiarradh, strangadh 'bend'; ríochan 'tauten'; teilgean 'make last'; dúiseacht 'wake up'; searradh 'stretch (limbs)'; caitheamh 'wear'; iompú ‘turn'; oscailt 'open'

PSYCH-VERBS: Agent/Cause, Recipient/Experiencer

stad 'surprise'; cliseadh 'startle'; leagan 'humble'; sásamh 'satisfy'; mealladh 'deceive'; amharc 'shock'

VERBS OF MOTION: Agent/Patient/Experiencer

titim, treascairt 'fall'; crith 'shudder'; rith 'run'; léim 'jump'

VERBS OF EXERTING FORCE: Agent, Patient/Affected Object

scracadh, stoitheadh, sreangadh 'pull, jerk'; tarraingt 'pull'; fáisc 'squeeze', croith 'shake' bogadh 'move'; corraí 'move, stir' 
VERBS OF NONVERBAL EXPRESSION ${ }^{18}$ : Agent/Cause

béic, liú 'yell, shout'; bloscadh 'explode (noise)'; glaoch 'call, cry'

Voluntary Agents or involuntary Causes bring about a change of state, produce a change of psychological or emotional state or cause an instantaneous involuntary reaction which is beyond the control of the Experiencer/Agent. It requires VNs with Patient/Affected Object/Experiencer and/or Agent/Cause in their thematic grid.

\subsubsection{Summary}

Let us round up our presentation of major sense groups associated with particular light verbs in a tabular form: ${ }^{19}$

\begin{tabular}{|l|c|c|c|c|}
\hline VERBS OF & déan & tabhair do & faigh & bain as \\
\hline COMMUNICATION & $\mathbf{X}$ & $\mathbf{x}$ & $\mathbf{x}$ & \\
\hline SOCIAL INTERACTION & $\mathbf{X}$ & $\mathbf{X}$ & $\mathbf{X}$ & \\
\hline CHANGE OF STATE & $\mathbf{x}$ & $\mathbf{x}$ & $\mathbf{X}$ & $\mathbf{X}$ \\
\hline MOTION & $\mathbf{X}$ & $\mathbf{x}$ & & $\mathbf{X}$ \\
\hline PSYCH-VERBS & & & $\mathbf{X}$ & $\mathbf{X}$ \\
\hline CHANGE OF POSSESSION & $\mathbf{x}$ & $\mathbf{x}$ & & \\
\hline CONTACT BY IMPACT & $\mathbf{x}$ & $\mathbf{X}$ & $\mathbf{X}$ & \\
\hline EXERTING FORCE & & $\mathbf{X}$ & & $\mathbf{X}$ \\
\hline $\begin{array}{l}\text { CREATION AND } \\
\text { TRANSFORMATION }\end{array}$ & $\mathbf{X}$ & & & \\
\hline NON-VERBAL EXPRESSION & & & & $\mathbf{X}$ \\
\hline PERCEPTION & $\mathbf{x}$ & $\mathbf{X}$ & $\mathbf{X}$ & \\
\hline
\end{tabular}

The general semantics of LVCs with particular light verbs is presented below:

\begin{tabular}{|l|l|}
\hline déan & action of a volitional Agent \\
\hline tabhair do & action of an Agent directed at some Recipient, Patient, Object \\
\hline faigh & only the Recipient/Patient or Experiencer in focus \\
\hline bain as & $\begin{array}{l}\text { Experiencer/Patient/Affected Object undergoing a process or } \\
\text { change effected by an Agent or non-volitional Cause }\end{array}$ \\
\hline
\end{tabular}

${ }^{18}$ The verb lig 'let' is found predominantly with (simplex) nouns relating to emission of sounds, as in lig sé fead, gáir, osna/liach, scread, sceamh 'to give a whistle, shout, sigh, scream, yelp’ (Ó Dónaill 1977: 783), gíog a ligean ‘to cheep, chirrup’ (Ó Dónaill 1977: 633).

$19 \mathbf{X}$ stands for a strong lexical association with a given class, whereas $\mathrm{x}$ denotes weaker collocability. 


\subsection{Semantic contribution of the light verb}

We hope to have demonstrated that a given light verb is not devoid of meaning and contributes to the overall understanding of an LVC. The choice of a particular light verb may further modify the meaning of the construction in a subtle way. ${ }^{20}$

As observed above, the domains of déan and tabhair partially overlap and in principle one could replace the other with no difference in meaning. Consider the following pairs of examples:

a. beannú Dé a thabairt do dhuine 'to greet s.o.' (Ó Dónaill 1977: 99)

Ní sin beannú ar bith le tabhairt do dhuine. 'That is no way to greet a person.' (Ó Dónaill 1977: 99)

b. "Laethanta Breátha" a thugaimísne mar leasainm orthu, ainm sheanabhlastúil, mar dhe ná raibh aon fhocal eile Gaeilge ina bpus ach an beannú so a dhéanfaidíst ar an mbóthar duit leis an dá focal - "Lá breá!"

'We used to call them 'Fine days' as a nickname, a sarcastic/contemptuous nickname as it were, because there was no other Irish word in their mouths than this greeting which they would use with you on the road - the two words '[It’s a] Fine day'.' (Ua Maoileoin 1960: 35)

(11)

a. Déan do ghoradh ag an tine. 'Warm yourself at the fire.' (de Bhaldraithe 1959: 828)

b. Thug sé goradh cúl chos dó féin. 'He warmed the back of his legs. He stood there with his back to the fire.' (Ó Dónaill 1977: 660)

a. moladh a dhéanamh ar dhuine 'speak in praise of s.o.' (Ó Dónaill 1977: 875)

b. moladh a thabhairt do dhuine 'praise s.o.' (Ó Dónaill 1977: 875)

The only difference seems to lie in the number of participants a given verb can accommodate:

a. tairiscint a dhéanamh ar rud 'make a bid for sth' (Ó Dónaill 1977: 1194)

b. Thug sé tairiscint mhaith dom air. 'He made me a good offer for it.' (Ó Dónaill 1977: 1194)

20 Consider the examples from Quirk et al. (1985: 752):

She gave a shriek. (an involuntary shriek)

She had a good shriek. (voluntary and for own enjoyment)

She did a (good) shriek. (a performance before an audience)

Following Wierzbicka (1982), Cetnarowska (1993) makes a case for the extra semantic modification on the part of the light verb in English. 
The most conspicuous contrast is that between intentional and involuntary actions. LVCs with déan and tabhair refer to a deliberate action whereas those with bain to causing an involuntary reaction in a human participant (bodily movement, emission of sound) or instigating some action of nonvolitional entities, as in e.g. pramsach a bhaint as duine 'to make s.o. jump' and pramsach a bhaint as an urlár 'pound the floor' (Ó Dónaill 1977: 967) respectively. In constructions with déan and tabhair the human participant actively controls the action whereas in structures with bain the human or non-human participant undergoes sth rather than does sth.

a. gáire doicheallach a dhéanamh 'to force a laugh, give a forced laugh' (de Bhaldraithe 1959: 399)

mise a rinne an gáire 'I had the laugh on my side’ (de Bhaldraithe 1959: 399)

Rinne siad gáire faoi. 'They laughed at him.' (Ó Dónaill 1977: 604)

Deirtear go ndearna an sagart a dhóthain gáirí.'It is said that the priest laughed a lot/enough.' (Ó Direáin 1961: 44)

b. gáire a bhaint as an gcuideachta 'to raise a laugh' (de Bhaldraithe 1959: 399) Bhainfeadh sé gáire as cat. 'It would make a cat laugh.' (Ó Dónaill 1977: 604)

(15)

a. Thug sé amharc géar orm. 'He gave me a sharp look.' (Ó Dónaill 1977: 40)

b. Bhain sé an t-amharc as mo shúile. 'It dazzled me, shocked me.' (Ó Dónaill 1977: 39)

a. Thug sé léim na díge. 'He jumped the ditch.' (Ó Dónaill 1977: 775)

b. léim a bhaint as duine 'make s.o. jump, startle s.o.' (Ó Dónaill 1977: 775)

(17)

a. leathoscailt a thabhairt ar do shúile 'to half open one's eyes' (de Bhaldraithe 1959: 494)

b. Is é an chéad leathadh a bhainfear as do shúile nuair a thiocfaidh tú i radharc Chuain Fionntrá.

'It will be the first time that your eyes open wide (in wonder) when you come in sight of Cuan Fionntrá.' (Ua Maoileoin 1960: 29)

When a volitional participant is involved the construction with bain implies lack of willingness or control, as in (18).

a. caint a dhéanamh le duine faoi rud 'to converse with s.o. about sth' (de Bhaldraithe 1959: 149) vs.

caint a bhaint as duine 'get s.o. to talk' (Ó Dónaill 1977: 174) 
b. Bainfidh mise sodar asat. 'I’ll make you hop.' (Ó Dónaill 1977: 1129)

crith a bhaint as duine 'make s.o. shudder' (Ó Dónaill 1977: 319)

dúiseacht a bhaint as duine 'to rouse up, startle s.o.' (Ó Dónaill 1977: 463)

cliseadh a bhaint as duine 'startle s.o.' (Ó Dónaill 1977: 246)

Baineadh titim asam. 'I stumbled and fell.' (Ó Dónaill 1977: 1242)

It can be argued that if an action is directed at a non-human participant the structures with bain and tabhair are equivalent. Consider (19a) and (19b) as well as similar pairs in (20).

(19)

a. Chomhairligh sé dá bhean a dhul agus píosa téide a cheangal d'ordóg choise an fhir óig agus tarraingt a thabhairt dó.

'He advised his wife to go and to tie a piece of rope to the big toe of a young man and give it a pull.’ (Ó Direáin 1961: 122)

b. Bhain sí tarraingt as mo mhuinchille. 'She tugged at my sleeve.' (Ó Dónaill 1977: 1211)

(20)

a. fáscadh a thabhairt do rud 'squeeze sth' (Ó Dónaill 1977: 520) vs.

fáscadh a bhaint as rud 'squeeze sth’ (Ó Dónaill 1977: 520)

b. fuarú a thabhairt do rud 'cool sth’ (Ó Dónaill 1977: 589) vs.

fuarú a bhaint as rud 'cool sth’ (Ó Dónaill 1977: 589)

c. Má thugann tú an úsáid cheart don speal 'If you use the scythe properly' (Ó Dónaill 1977: 1307) vs.

Ní baintí aon úsáid eile as an méis bheag dheas san, go dtí go dtagadh Lá Coille arís.

'That nice little dish wouldn't be used again for anything until New Year's Day would come again’ (Ó Dálaigh 1933: 90).

If intransitive verbs of motion refer to an action that can be prolonged over a period of time, in an LVC with déan we refer to an unspecified but limited portion whereas in an LVC with bain we refer to the inceptive stage of the activity, as in (21a-b) and (21c) respectively:

(21)

a. N'fhéadann sé aon tseasamh a dhéanamh sa tsneachta, mar má théigheann sé ar lár ann, bíonn sé ró-lag chun é féin a tharrac as (...).

'He can't stand in the snow (do any standing in the snow), because if he goes on the bare ground, he is too weak to pull himself out...'

(Ó Dálaigh 1933: 8)

b. Bhí iontas ar an Ollamh nach raibh mé ag déanamh níos mó snámha.

'The professor was surprised why I was not swimming more/doing more swimming. ' (Ó Direáin 1961: 137) 
c. rith a bhaint as duine 'make s.o. run' (Ó Dónaill 1977: 1003)

If the complement is polysemous, in an LVC it will receive one of its predominant readings depending on the light verb.

(22)

a. súisteáil a thabhairt do dhuine 'to thrash s.o.' - (verb of infliction)

(Ó Dónaill 1977: 1183) vs.

Tá súisteáil mhaith déanta acu. 'They have done a good bit of threshing' (verb of creation and transformation) (Ó Dónaill 1977: 1183)

b. sciúradh a thabhairt do rud 'give sth a scrub' (verb of exerting force) (Ó Dónaill 1977: 1056) vs.

fuair sé sciúradh na cuinneoige 'he got quite a drubbing, he was told off in no uncertain manner’ (verb of social interaction) (Ó Dónaill 1977: 1056)

c. stánáil a thabhairt do dhuine 'to give s.o. a drubbing' (verb of infliction) (Ó Dónaill 1977: 1162) vs.

stánáil a dhéanamh ort féin le bia 'to stuff oneself with food' (verb of ingesting) (Ó Dónaill 1977: 1162)

\section{Conclusion}

The construction in question imposes a telic reading upon the situation denoted by the verb acting as the base for the VN. In addition to providing aspectual distinctions, particular light verbs combine with nominalisations derived from various semantic classes of verbs in order to present a situation from different angles by giving prominence to certain participants (Agent, Patient, Experiencer) and to bring out some nuances of meaning such as volitionality. It is to be underlined that this paper is only a preliminary study which merely marks paths at which further research should be directed and the tentative proposals advanced here should of course be verified against a greater body of data. ${ }^{21}$

John Paul II Catholic University of Lublin, Poland

\footnotetext{
${ }^{21}$ I would like to express my heartfelt thanks to Dr Maxim Fomin for investing a great deal of time and effort in editing this paper.
} 


\section{References}

Biber, D., Johansson, S., Leech, G., Conard, S. \& Finegan, E., 1999, Longman Grammar of Spoken and Written English, London: Pearson Education Ltd.

Bloch-Rozmej, A., ed., 2008, Issues in Celtic Linguistics. Lublin Studies in Celtic Languages 5, Lublin: Wydawnictwo KUL.

Bloch-Trojnar, M., ed., 2009, Perspectives on Celtic Languages. Lublin Studies in Celtic Languages 6, Lublin: Wydawnictwo KUL.

Bloch-Trojnar, M., 2006, Polyfunctionality in Morphology. A Study of Verbal Nouns in Modern Irish, Lublin: Wydawnictwo KUL.

Bloch-Trojnar, M., 2009a, 'On the Nominal Status of VNs in Light Verb Constructions in Modern Irish', in: Kuźniak, M. \& Rozwadowska, B., eds., 25-33.

Bloch-Trojnar, M., 2009b, 'Aspectual Characteristics of Light Verb Constructions in Modern Irish', in: Bloch-Trojnar, M., ed., 63-85.

Brinton, L., 1988, The Development of English Aspectual Systems, Cambridge: Cambridge University Press.

Brinton, L., 1998, 'Aspectuality and Countability: a Cross-categorial Analogy', English Language and Linguistics 2, 37-63.

Butt, M. \& Geuder, W., 2001, 'On the (Semi)Lexical Status of Light Verbs’, in: Corver, N. \& van Riemsdijk, H., eds., 323-370.

Butt, M., 2003, 'The Light Verb Jungle', (available on-line: http://ling.unikonstanz.de/pages/home/butt/harvard-work.pdf).

Cattell, R., 1984, Composite Predicates in English, Sydney: Academic Press.

Cetnarowska, B., 1993, The Syntax, Semantics and Derivation of Bare Nominalisations in English, Katowice: Uniwersytet Śląski.

Corver, N. \& van Riemsdijk, H., eds., 2001, Semilexical Categories: On the Content of Function Words and the Function of Content Words, Berlin: Mouton de Gruyter.

de Bhaldraithe, T., 1959 [1992], English-Irish Dictionary, Baile Átha Cliath: An Gúm.

Dinneen, P. S., 1927, Irish-English Dictionary, Dublin: Irish Texts Society.

Grimshaw, J. \& Mester, A., 1988, 'Light Verbs and $\theta$-marking', Linguistic Inquiry 19.2, 205-232.

Jackendoff, R., 1974, ‘A Deep Structure Projection Rule’, Linguistic Inquiry 5, 481-505.

Jayaseelan, K. A., 1988, 'Complex Predicates and $\theta$-Theory', in: Wilkins, W., ed., 91-111.

Jespersen, O., 1954, A Modern English Grammar. Vol. VI., London: George Allen and Unwin Ltd. 
Kearns, K., 2002, 'Light Verbs in English', (available on-line: http://www.ling.canterbury.ac.nz/kate/lightverbs.pdf).

Kuźniak, M. \& Rozwadowska, B., eds., 2009, PASE Papers 2008. Vol.1. Studies in Language and Methodology of Teaching Foreign Languages, Wrocław: Oficyna Wydawnicza ATUT.

Langacker, R. W., 1987, 'Nouns and Verbs', Language 63, 53-94.

Levin, B., 1993, English Verb Classes and Alternations. A Preliminary Investigation, Chicago and London: The University of Chicago Press.

Macaulay, D., ed., 1992, The Celtic Languages, Cambridge: Cambridge University Press.

Mag Uidhir, S., 1944, Fánaidheacht i gConndae Mhuigheo, Baile Átha Cliath: Oifig an tSoláthair.

Ó Baoill, D. \& Ó Tuathail, É., 1992, Úrchúrsa Gaeilge, Baile Átha Cliath: Institiúid Teangeolaíochta Éireann.

Ó Dálaigh, S., 1933, Timcheall C hinn Sl éibhe, Baile Átha Cliath: Foillseacháin Rialtais.

Ó Direáin, M., 1961, Feamainn B healtaine, Baile Átha Cliath: An Clóchomhar.

Ó Dochartaigh, C., 1992, ‘The Irish Language’, in: Macaulay, D., ed., 1199.

Ó Dónaill, N., 1977, Foclóir Gaeilge-Béarla, Baile Átha Cliath: An Gúm.

Ó Duibhín, C., 2006, Tobar na Gaedhilge (version 1.3; available on-line: http://www.smo.uhi.ac.uk/ oduibhin/tobar/index.htm).

Ó hAnluain, L. A., 1999, Graiméar Gaeilge na m Bráithre Críostaí, Baile Átha Cliath: An Gúm.

Ó Ruadháin, S., 1967, An Mothall Sin Ort, Baile Átha Cliath: Oifig an tSoláthair.

Ó Siadhail, M., 1989, Modern Irish. Grammatical Structure and Dialectal Variation, Cambridge: Cambridge University Press.

Piñango, M., Mack, J., \& Jackendoff, R., 2006, 'Semantic Combinatorial Processes in Argument Structure: Evidence from Light-Verbs', (available on-line: http://www.yale.edu/linguist/ psychoneurolinglab/PinangoMack\&Jackendoff_2006_BLS.pdf).

Quirk, R., Greenbaum, S., Leech, G., \& Svartvik, J., 1985, A Comprehensive Grammar of the English L anguage, London and New York: Longman.

Stevenson, S., Fazly, A., \& North, R., 2004, 'Statistical Measures of the Semi-productivity of Light Verb Constructions' (available on-line: http://www.qwantz.com/mwe04-ref.pdf).

Ua Maoileoin, P., 1960, Na hÁird ó Thuaidh, Baile Átha Cliath: Sáirséal Agus Dill. 
Vendler, Z., 1967, Linguistics in Philosophy, New York: Cornell University Press.

Wagner, H., 1958-1969, Linguistic Atlas and Survey of Irish Dialects, Dublin: Dublin Institute for Advanced Studies.

Wierzbicka, A., 1982, 'Why can you Have a Drink when you can't *Have an Eat?', Language 58(4), 753-799.

Wigger, A., 2008, 'Advances in the Lexicography of Modern Irish Verbs', in: Bloch-Rozmej, A., ed., 233-250.

Wilkins, W., ed., 1988, Thematic Relations: Syntax and Semantics, San Diego: Academic Press Inc.

Willim, E., 2006, Event, Individuation, and Countability: A Study with Special Reference to English and Polish, Kraków: Jagiellonian University Press. 